\title{
СИМБІОЗ ЛІТЕРАТУРИ І КІНЕМАТОГРАФА У ТВОРЧОСТІ УКРАЇНСЬКОГО МИТЦЯ М. С. ВІНГРАНОВСЬКОГО
}

У статті досліджено симбіоз літератури (поезії і прози) та кінематографа (ігрового та документального кіно) у творчій діяльності геніального украӥнського поета, письменника, кінорежисера, кіноактора, сиенариста, заслуженого діяча мистеитв України, лауреата Національної премії України імені Тараса Шевченка Миколи Степановича Вінграновського, якому в 2016 рочі виповнилося б вісімдесят років. Наведено список поетичних і прозових творів; розказано про художні й документальні фільми, зняті М. Вінграновським в Украӥні.

Ключові слова: Микола Степанович Вінграновський, Олександр Петрович Довженко, симбіоз, література, кінематограф, творча діяльність.

В статье исследован симбиоз литературы (поэзии и прозы) и кинематографа (игрового и документального кино) в творческой деятельности гениального украинского поэта, писателя, кинорежиссера, киноактера, сиенариста, заслуженного деятеля искусств Украины, лауреата Национальной премии Украины имени Тараса Шевченко Николая Степановича Винграновского, которому в 2016 году исполнилось бы восемьдесят лет. Приведен список поэтических и прозаических произведений; рассказано о художественных и документальных фильмах, снятых Н. Винграновским в Украине.

Ключевые слова: Николай Степанович Винграновский, Александр Петрович Довженко, симбиоз, литература, кинематограф, творческая деятельность.

In this article investigational symbiosis of literature (poetries and proses) and cinema (future and documentary cinema) creative activity of the of genius Ukrainian poet, writer, film director, movie actor, scenario writer, Honoured Worker of Arts of Ukraine, Laureate of the Taras Shevchenko's National Premium of Ukraine Mykola S. Vingranovskyi, 2016 year there would be eighty years was born.Autor brought the list over of poetic and prosaic works of Mykola S. Vingranovskyi; told about feature and documentary films, made by Mykola S. Vingranovskyi in Ukraine.

Key words: Mykola S. Vingranovskyi, Oleksandr Dovzhenko, symbiosis, literature, cinema, creative activity.

Актуальність цього дослідження зумовлена потребою вивчення творчої спадщини провідних вітчизняних митців, які зробили багато для розбудови української культури. Одним із них є геніальний український поет і письменник-«шістдесятник», кінорежисер, кіноактор, сценарист, заслужений діяч мистецтв України (1997), лауреат Національної премії імені Тараса Шевченка (1984), премії Фундації Антоновичів (1993), премії ім. В. Вернадського (2002) Микола Степанович Вінграновський (07. 11. 1936, с. Богопіль Микол. обл. (нині м. Первомайськ) - 26. 05. 2004, Київ).

Його літературна спадщина вивчається в українських школах і вищих навчальних закладах, науково-дослідних інститутах Національної академії наук України і Національної академії мистецтв України, значно меншою мірою прова- дяться дослідження його кінематографічних здобутків.

Проблема, якій присвячується дослідження, полягає в тому, що українськими мистецтвознавцями недостатньо досліджувалася літературна i кінематографічна діяльність М. С. Вінграновського як симбіоз двох видів мистецтва. I це особливо важливо у контексті нещодавного вісімдесятирічного ювілею митця.

Виходячи $з$ проблеми, визначимо мету дослідження: проаналізувати та дослідити симбіоз літературної та кінематографічної діяльності видатного українського поета і письменника-«шістдесятника», кінорежисера, кіноактора, сценариста М. С. Вінграновського.

Про життя, літературну і кінематографічну діяльність М. Вінграновського писали багато укра- 
їнських і закордонних мистецтвознавців і діячів культури, зокрема, О. Білинкевич [1], Л.Брюховецька [2], Л. Голота [3], А. Добролежа [4], І. Зубавіна [5], В. Ілляшенко [6], А. Кульчицький [7], Б. Олійник [8], Р. Сергієнко [9; 10; 11], О. Сизоненко [12], В. Скуратівський [13], Й. Струцюк [14], Г. Холод [15], А. Яремчук [16], О. Безручко [17] та ін. Одначе, зважаючи на масштаб митця, можна констатувати, що життєвий і творчий шлях Миколи Степановича Вінграновського досліджений ще недостатньо.

Науковими завданнями цієї статті є дослідити симбіоз літературної і кінематографічної діяльності геніального українського поета і письменника, кінорежисера і кіноактора М. С. Вінграновського; назвати його основні літературні твори; реконструювати його творчу діяльність у кінематографі як актора, сценариста і режисера художніх та документальних фільмів; окреслити ситуацію специфікою поєднання двох видів мистецтва у творчій діяльності.

У геніальному українському поетові і письменнику-шістдесятнику, кінорежисерові й кіноактору, заслуженому діячу мистецтв України (1997), лауреатові Національної премії імені Тараса Шевченка (1984), премії Фундації Антоновичів (1993), премії ім. В. Вернадського (2002) М. Вінграновському, якому у 2016 році виповнилося б вісімдесят років, унікально вдало поєднувалися літератор і кінематографіст: «Як поет, я дуже вдячний кіно за зорову систему мислення. А як режисер вдячний поезії за ііі інтуїтивне почуття ритму, паузи. За почуття міри. Принаймні я ще не посварився 3 собою і лечу на двох крилах» $[18,2]$.

У 1955 Микола Вінграновський вступив на акторський відділ до Київського державного інституту театрального мистецтва ім. І. К. Карпенка-Карого (КДІТМ, нині - Київський національний університет театру, кіно і телебачення ім. І. К. Карпенка-Карого), проте менш ніж за два тижні продовжив навчання у майстерні режисерів художнього фільму під керівництвом О. П. Довженка у Всесоюзному державному інституті кінематографії (ВДІК, нині - Всеросійський державний університет кінематографії ім. С. А. Герасимова).

Серед однокурсників М. Вінграновського були Р. Сергієнко, Л. Шепітько, О. Іоселіані, Г. Шенгелая, В. Туров, О. Косачов, Д. Фірсова та інші видатні кінематографісти. Більшість учнів режисерської майстерні ВДІКу стали справжніми майстрами, і немає значення, в якій царині мистецтва вони збудували власний храм - в ігровому кіно чи в документальному; в акторській грі чи у віршах, - головне, що вони, як того бажав Довженко, стали передусім справжніми людьми, а декому з них, за думкою О. Іоселіані, Олександр Довженко накреслив весь життєвий шлях: «Українці, як і він сам, - вони все своє життя орієнтувалися на нього» $[19,38]$.

1957 року перші вірші студента-режисера ВДІКу Вінграновського були надруковані на сторінках журналів «Дніпро» $(1957$, ч. 2), «Жовтень» (1958, ч. 8, нині - «Дзвін»), «Вітчизна» (1960, ч. 5), «Прапор» (1960, ч. 8, нині - «Березіль») тощо.

Ще студентом кіновузу М. Вінграновський зіграв головну роль - Івана Орлюка у широкоформатному художньому фільмі «Повість полум'яних літ», знятому у 1961році на кіностудії «Мосфільм» Юлією Солнцевою за сценарієм Олександра Довженка. М. Вінграновський вважав, що втілив на екрані самого видатного режисера: «Мій учитель Олександр Довженко у своєму щоденнику писав: “Іван Орлюк - це я, Довженко". Отже, у якійсь мірі я зіграв у цьому фільмі самого Довженка... Горджуся, що мав змогу зустрічатися 3 великим художником, учитися в нього» [20].

Проте молодому дипломованому випускнику єдиного в СРСР кінематографічного вузу, чиє обличчя впізнавали на афішах «Повісті полум'яних літ», розклеєних по всьому Києву, на Київській кіностудії художніх фільмів, яка мала ім'я його вчителя, довго не вдавалося запуститися з власним режисерським дебютом ні зі сценарієм «Світ без війни» 1962 р. [21], ані з екранізацією роману О. Гончара «Людина і зброя» 1963 р. [4].

Відсутність творчих перспектив та безгрошів'я призводили до того, що молодий режисер і поет погоджувався на будь-яку роботу на Київській кіностудії, тому знявся в епізодичній ролі сержанта, який грав на роялі (ця роль не була навіть зазначена у титрах) у фільмі Сергія Параджанова «Українська рапсодія» (1961) та виконав роль Дончака у фільмі Ісака Шмарука «Сейм виходить $з$ берегів» (1962).

Утім, М.С. Вінграновський довів власну творчу спроможність, знявши надалі як режисер-постановник на Київській кіностудії художніх фільмів ім. О. П. Довженка та Одеській кіностудії художніх фільмів п'ять повнометражних художніх фільмів: «Ескадра повертає на захід» (1966, спільно з Мироном Львовичем Билинським), «Берег надії» (1967, - роль Вацлава Купки), «Дума про Британку» (1969, - роль Несвятипаски), «Тихі береги» (1972), «Климко» (1984).

Сімдесяті роки характерні в українському культурному просторі «закручуванням гайок»: в екран- 
них мистецтвах викорчовувався український поетичний кінематограф, у літературі - ширилися гоніння письменників і поетів-шістдесятників.

У 70-х рр. був досить тривалий період, коли М. Вінграновський не працював у кінематографі. Проте в цей час він активно подорожував, збираючи нові враження для майбутніх творів і працював здебільшого, як казали митці, «в шухляду». Зважаючи на «залізну завісу», митець багато мандрував винятково Радянським Союзом. Сам Вінграновський це називав непоборною жадобою подорожей, завдяки якій він тільки 1978 року «“намотав”, як кажуть, понад 25 тисяч кілометрів. Це не просто кілометри, це - люди, їх долі, їх робота, думки, пристрасті, їх день вчорашній i день завтрашній... Це, зрештою, і не бачені досі куточки землі, і комарі, і готелі, і підігріта на тайговому багаті консервна банка “Солянки”... Одне слово, все у цих подорожах головне. Я побував на БАМі, в Тюмені, в Середній Азії, на Крайній Півночі» [20].

У своїх поезіях і фільмах М.С.Вінграновський, як і його вчитель О.П. Довженко прагнув працювати над великими і важливими для людства темами: «У художніх широкоформатних фільмах «Дума про Британку», «Берег надії» я намагався вирішити глобальні проблеми людства (перший твір - про громадянську війну на Україні, другий присвячений найгострішій проблемі сучасності збереженню миру на планеті)» [20].

1984 року М. С. Вінграновський за збірки творів для дітей «Літній ранок», «Літній вечір», «Ластівка біля вікна», «На добраніч» став лауреатом Державної премії УРСР імені Тараса Шевченка (нині - Національна премія України імені Тараса Шевченка) [22]. Проте лауреатові найпрестижнішої мистецької премії в Україні більше не дали зняти жодного ігрового фільму, тому він зосередився на документальних фільмах і літературі.

У цьому Микола Вінграновський наслідував свого вчителя Олександра Довженка, який за неможливості творчого виявлення в одному виді мистецтва, працював в іншому, а тому зумів реалізуватися, попри численні перепони. М.Вінграновський вважав, що «усім, або майже усім, чого я досяг як кінорежисер і як письменник, я зобов'язаний своєму вчителеві, тій школі, яку він мені дав. Без школи - нема таланту» [20].

Саме тому митець написав спогади про О. Довженка «Рік з Довженком» [23; 24; 25], «Голос таланту, мужності і любові» [26] та зняв документальні фільми за власними сценаріями про вчителя: «Щоденник О. П. Довженка» (у співавт. 3 Ле- онідом Осикою, 1989) та «Довженко. Щоденник 1941-1945 роки» (1993).

Учитель був для Вінграновського камертоном у житті та творчості: «Що б я не написав, я перевіряю на Довженкові, на цьому живому класикові - бо я його знав, любив, він був мені мірилом. Коли знав живого чоловіка, то ти пам'ятаєш його голос, його слова» [3].

М. Вінграновський зняв документальні фільми: «Голубі сестри людей» (1966), «Слово про Андрія Малишка» (1983), «Щоденник О.П. Довженка» (у співавт. $з$ Леонідом Осикою, 1989) та «Довженко. Щоденник 1941-1945 роки» (1993), «Хортиця - столиця Запорозької Січі» (1993), «Дмитро Вишневецький — Байда» (1993), «Чигирин - столиця гетьмана Богдана Хмельницького» (1994), «Батурин - столиця гетьмана Івана Мазепи» (1994), «Галич - столиця князя Данила Галицького» (1995), «Гетьман Сагайдачний» (1999).

Як справжній патріот України М. Вінграновський вивчав і популяризував історію власної Батьківщини в літературі й кінематографі. Варто згадати хоча б «Чотирнадцять столиць України: короткі нариси з їі історії» [27]. А. Кульчицький зазначав: «Вінграновський свого часу задумав створити цикл документальних фільмів, присвячених історії України (більше 40)» [7, 10]. Проте М. Вінграновський встиг зняти лише восьму частину із запланованої серії.

Найбільш вдалими із своїх фільмів М. Вінграновський вважав «насамперед ті, які я поставив за власними сценаріями. Так вважаю не тільки я, а й мої друзі. І це, мабуть, справедливо. Коли сценарист і режисер-постановник є однією особою, відкриваються широкі можливості у досягненні художньої довершеності твору, процес роботи не перериваєтеся, він розвивається від першої написаної ремарки в сценарії до останньої безсонної ночі режисера за монтажним столом» [20].

Окрім повнометражного художнього фільму «Климко», режисер був автором сценаріїв власних документальних фільмів. Принаймні два сценарії повнометражних художніх фільмів «Світ без війни» та «Северин Наливайко» так і залишились нереалізованими.

Також за сценарієм Миколи Вінграновського, в основу якого була покладена його повість «Сіроманець», 1989 року на Київській кіностудії художніх фільмів Петро Марусик зняв однойменний фільм.

Незважаючи на усі перепони в літературній i кінематографічній творчості, Вінграновський 
в житті намагався бути щиросердним і спокійним, любив подорожувати, знайомитися з новими людьми, які надихали його на створення нових образів, написання літературних та екранних творів. Вдале поєднання М. С. Вінграновським в одній особі актора, сценариста, режисера 3 поетом і письменником стало можливо через душевний спокій: «Дуже важливо не посваритися з собою. Бо душевний неспокій приносить суєту, випадковість, а цього не терплять ні кіно, ні поезія. Кіно допомагає поетові писати "видимі" вірші. Читач в них бачить і колір, і конкретні деталі, відчуває рух. А поезія допомагає режисерові створювати стрічки, сповнені певного характерного саме для цього митця, ритму» $[18,2]$.

У літературному творчому доробку М. С. Вінграновського збірки віршів: «Атомні прелюди» (1962), «Сто поезій» (1966), «Поезії» (1971), «На срібнім березі» (1978), «Київ» (1982), «Губами теплими і оком золотим» (1984), «Цю жінку я люблю» (1990), «3 обійнятих тобою днів» (1993), «Любове, ні! Не прощавай!» (1996), «Сеньйорито акаціє» (1994); повісті «Світ без війни» (1958), «Президент» (1960), «Первинка» (1971), «Сіроманець» (1977), «У глибині дощів» (1979), «Літо на Десні» (1983), «Кінь на вечірній зорі» (1986), «Манюня» (2003); роман «Северин Наливайко» (1996); історичний нарис «Чотирнадцять столиць України» (1997).

Микола Вінграновський написав також декілька поетичних книжок для дітей: «Андрійко-говорійко» (1970), «Мак» (1970), «Літній ранок» (1976), «Літній вечір» (1979), «Ластівка біля вікна» (1983), «У неквапи білі лапи» (1989), «Іде кіт через лід» (2000), «Козак Петро Мамарига» (2001); оповідання «Гусенятко» (1978), «Низенько пов'язана» (1985) тощо.

Літературну творчість М.С. Вінграновського вивчають у школах та інститутах. Про митця його колишній одногрупник по майстерні О.П.Довженка і щирий товариш протягом усього життя Р. П. Сергієнко написав спогади $[9 ; 10]$ та зняв документальний фільм «Микола Вінграновський у синьому небі. Сповідь перед другом» (2006) [11], в якому Джемма Фірсова, Ірина Поволоцька, Іван Драч та інші відомі діячі культури згадували про видатного українського поета і прозаїка, кінорежисера, актора, лауреата Національної премії імені Тараса Шевченка Миколу Вінграновського [28; 29].

Петро Мисик, крім екранізації (1989 р.) повісті М. Вінграновського «Сіроманець», у 1993 році зняв повнометражний документальний фільм «Микола Вінграновський», де зафіксовано митця, «який читав свої вірші. Причому режисер делікатно й тактовно чергував поета в кадрі й пейзажі, що жили своїм активним життям, озвучені рафінованим словом» [2]. Фактично це був симбіоз кінематографа і літератури, як, до речі, і вся творчість видатного українського митця.

Фактично, за образним висловом самого Миколи Вінграновського, все його життя і творчість - це політ на двох крилах, одне з яких література, друге - кінематограф.

Підсумовуючи вищевикладене, можна зазначити, що поставлені наукові завдання виконані: досліджено симбіоз літературної і кінематографічної діяльності геніального українського поета i письменника, кінорежисера i кіноактора М. С. Вінграновського; названо його основні літературні твори, реконструйовано його творчу діяльність у кінематографі як актора, сценариста і режисера художніх та документальних фільмів; 3'ясовано ситуацію зі специфікою поєднання двох видів мистецтва у творчій діяльності.

Однак, зважаючи на масштаб значення Миколи Степановича Вінграновського для української культури, перспективи наукових розвідок життя, літературної і кінематографічної діяльності митця залишаються великими.

\section{Джерела та література}

1. Білинкевич О. Трохи про Миколу / О. Білинкевич // Сучасність. - 2009. - Чис. 11. - С. 170-191.

2. Брюховецька Л.Спілкування 3 Миколою Вінграновським / Л. Брюховецька // Кіно-Театр. - 2016. — № 4. C. 35 .

3. Голота Л. Микола Вінграновський: «Я - Микола осінній...» [Текст] / Любов Голота // Слово Просвіти. 2006. — № 44 (2-8 листопада). — С. 8. (До 70-річчя від дня народження).

4. 4. Добролежа А. Микола Вінграновський у спогадах, листах і кіно : до 70-річчя поета, кінорежисера, кіноактора / Анатолій Добролежа // Вітчизна. - 2006. — № 9/10. C. $128-134$.

5. Зубавіна І. Кінематограф незалежної України: тенденції, фільми, постаті / І. Зубавіна ; [авт. вступ. ст. В. Сидоренко ; літ. ред. Ю. Щербак] ; [АМУ], Ін-т пробл. сучас. мистец. - К. : Фенікс, 2007. — 296 с. : іл.

6. 6. Ілляшенко В.Етюди про кіно : [мемуари]. [Кн. 3] / В. Ілляшенко. - Переяслав-Хмельницький : вид-во КСВ, 2011. - $193 \mathrm{c}$.

7. Кульчицький А. 212 спогадів з Миколою Вінграновським. Фрагменти спогадів про великого Українця / А. Кульчицький // Літературна Україна. - 2011. - 4 серп. - С. 1011.

8. Олійник Б. 212 світанків з Миколою Вінграновським : фрагменти спогадів про великого Українця / Б. Олійник // Літературна Україна. - 2011. - 4 серп. - С. 10-11.

9. Сергієнко Р. ...І твої божественні вірші : відкр. лист до Миколи Вінграновського 3 нагоди ювілею побратима студентської юності / Ролан Сергієнко // Вітчизна. 1996. — № 11/12. — C. 124-128. 
10. Сергієнко Р. ...І твої божественні вірші: відкр. лист до Миколи Вінграновського з нагоди ювілею побратима студентської юності / Ролан Сергієнко // Кур'єр Кривбасу. 2006. — № 203. - C. 160-174.

11. Сергієнко Р. «Микола Вінграновський. «У синьому небі...» : режис. сцен. докум. відеофільму / Р. П. Сергієнко, М. В. Макаренко // Кур'єр Кривбасу. - 2006. № 203. - С. 174-179.

12. Сизоненко О.Степовий наш Гайявата / О. Сизоненко // Вітчизна. - 2001. - № 1/2. - С. 96-106.

13. Скуратівський В.Нероздільність творчого й патріотичного : [пам'яті М. Вінграновського] / В. Скуратівський // Дзеркало тижня. - 2004. - 29 трав. —4 черв. (№ 21). С. 18.

14. Струцюк Й. Вітер часу і наші вітрила / Й. Струцюк // Кур’єр Кривбасу. - 2006. - № 204. - С. 175-180.

15. Холод Г. Я. Поетика прози Миколи Вінграновського : монографія / Г. Я.Холод. - Київ, 2016. - 199 с.

16. Яремчук А. Він випестив перо любов’ю : 26 трав. 2004 р. пішов у вічність видат. укр. поет, прозаїк, кінореж. і кіноактор М. Вінграновський / А. Яремчук // Укр. культуpa. - 2004. - № 6/7. - С. 1 .

17. Безручко О. Витоки творчої діяльності видатного українського кінематографіста і поета М. С. Вінграновського / О.Безручко // Сучасне мистецтво: науковий збірник / ІПСМ НАМ України ; редкол. : В. Д. Сидоренко (голова редколегії), А. О. Пучков (заступник голови редколегії), Л.А. Дрофань (учений секретар) та ін. - К. : Фенікс, 2016. - Вип. XII. - С. 43-47.

18. Афоніна А.Режисер і поет / А. Афоніна // На екранах України. - 1969. - 23 серп. - С. 2.

19. Іоселіані О.Навчаючись у Довженка / О.Іоселіані // КІNO-КОЛО.

20. Савчак В. Уроки великого майстра / В. Савчак // Ленінська молодь (Львів). - 1978. — 11 лютого.

21. Вінграновський М. Хто і що для мене незалежність України / М. Вінграновський // День. - 2001. - 6 вересня, № 159 .

22. Наші земляки - лауреати премії ім. Т. Г. Шевченка // Південна правда. - 1984. - 13 берез.

23. Винграновский Н. Год с учителем // Довженко в воспоминаниях современников [Текст] : Сборник. - М. : Искусство, 1981. - С. 231-233.

24. Вінграновський М. Рік $з$ Довженком / М. Вінграновський // Вінграновський М. Вибрані твори / Микола Вінграновський ; [передм. Л. М. Талалая]. - К. : Дніпро, 2004. - С. 767-775.

25. Вінграновський М. Рік з Довженком / М. Вінграновський // Вінграновський М. Вибрані твори. У 3 т. Т. 3. Повісті й оповід. / Микола Вінграновський ; [передм. Т. Салиги]. — Т. : Богдан, 2004. - С. 342-350.

26. Вінграновський М. Голос таланту, мужності і любові / Микола Вінграновський // Кур'єр Кривбасу. — 1995. № 27. - C. 18-20.

27. Вінграновський М. С. Чотирнадцять столиць України: короткі нариси з її історії / М. С. Вінграновський ; [голов. ред. Л. Н. Головко ; пер. з укр. на рум. мову М. С. Лютика, худож. оформ. Ж. Присяжної]. - Київ : Голов. спец. ред. л-ри мовами нац. меншин України, 2002. - 175 с. : іл.

28. Білан А. Фільм про друга як сповідь перед собою / А. Білан // Укр. культура. — 2007. — № 3. - С. 13.

29. Литвин М. Творив життя, як вірш / Марія Литвин // Культура і життя. — 2007. - 14 берез. (№ 11). — С. 2.

\section{References}

1. Bilynkevych, O. Trokhy pro Mykolu / O. Bilynkevych // Suchasnist. - 2009. - Chys. 11. - S. 170-191.
2. Briukhovetska, L. Spilkuvannia z Mykoloiu Vinhranovskym / L. Briukhovetska // Kino-Teatr. - 2016. - № 4. - S. 35.

3. Holota, L. Mykola Vinhranovskyi: «Ia - Mykola osinnii...» [Tekst] / Liubov Holota // Slovo Prosvity. - 2006. - № 44 (2-8 lystopada). - S. 8. (Do 70-richchia z dnia narodzhennia).

4. Dobrolezha, A. Mykola Vinhranovskyi u spohadakh, lystakh i kino : do 70-richchia poeta, kinorezh., kinoaktora / Anatolii Dobrolezha // Vitchyzna. — 2006. — № 9/10. - S. 128-134.

5. Zubavina, I. Kinematohraf nezalezhnoi Ukrainy: tendentsii, filmy, postati / I. Zubavina ; [avt. vstup. st. V. Sydorenko ; lit. red. Yu. Shcherbak] ; [AMU], In-t probl. suchas. mystets. K. : Feniks, 2007. - 296 s. : il.

6. Illiashenko, V. Etiudy pro kino : [memuary]. [Kn. 3] / V. Illiashenko. - Pereiaslav-Khmelnytskyi : Vyd-vo KSV, 2011. - $193 \mathrm{~s}$.

7. Kulchytskyi, A. 212 spohadiv z Mykoloiu Vinhranovskym. Frahmenty spohadiv pro velykoho Ukraintsia / A. Kulchytskyi // Literaturna Ukraina. — 2011. — 4 serp. S. $10-11$.

8. Oliinyk, B. 212 svitankiv z Mykoloiu Vinhranovskym : frahmenty spohadiv pro velykoho Ukraintsia / B. Oliinyk // Literaturna Ukraina. - 2011. - 4 serp. - S. 10-11.

9. Serhiienko, R. ...I tvoi bozhestvenni virshi : vidkr. lyst do Mykoly Vinhranovskoho z nahody yuvileiu pobratyma student. yunosti / Rolan Serhiienko // Vitchyzna. — 1996. № 11/12. - S. 124-128.

10. Serhiienko, R. ...I tvoi bozhestvenni virshi: vidkr. lyst do Mykoly Vinhranovskoho $\mathrm{z}$ nahody yuvileiu pobratyma student. yunosti / Rolan Serhiienko // Kurier Kryvbasu. 2006. 一 № 203. - S. 160-174.

11. Serhiienko, R. «Mykola Vinhranovskyi. «U synomu nebi...» : rezhys. stsen. dokum. videofilmu / R. P. Serhiienko, M. V. Makarenko // Kurier Kryvbasu. — 2006. — № 203. S. 174-179.

12. Syzonenko, O. Stepovyi nash Haiiavata / O. Syzonenko // Vitchyzna. - 2001. - № 1/2. - S. 96-106.

13. Skurativskyi, V. Nerozdilnist tvorchoho y patriotychnoho : [pamiati M. Vinhranovskoho] / V. Skurativskyi // Dzerkalo tyzhnia. -2004 . -29 trav. -4 cherv. (№ 21). - S. 18

14. Strutsiuk, Y. Viter chasu i nashi vitryla / Y. Strutsiuk // Kurier Kryvbasu. - 2006. - № 204. - S. 175-180.

15. 15. Kholod, H. Ya. Poetyka prozy Mykoly Vinhranovskoho: monohrafiia / H. Ya. Kholod. - Kyiv, 2016. - $199 \mathrm{~s}$.

16. Yaremchuk, A. Vin vypestyv pero liuboviu : 26 trav. 2004 r. pishov u vichnist vydat. ukr. poet, prozaik, kinorezh. i kinoaktor M. Vinhranovskyi / A. Yaremchuk // Ukr. kultura. - 2004. - № 6/7. - S. 1 .

17. Bezruchko, O. Vytoky tvorchoi diialnosti vydatnoho ukrainskoho kinematohrafista i poeta M. S. Vinhranovskoho / O. Bezruchko // Suchasne mystetstvo: naukovyi zbirnyk / IPSM NAM Ukrainy; Redkol.: V. D. Sydorenko (holova redkolehii), A. O. Puchkov (zastupnyk holovy redkolehii), L. A. Drofan (uchenyi sekretar) ta in. - K.: Feniks, 2016. Vyp. XII. - S. 43-47.

18. Afonina, A. Rezhyser i poet / A. Afonina // Na ekranakh Ukrainy. - 1969. - 23 serp. - S. 2.

19. Ioseliani, O. Navchaiuchys u Dovzhenka / O. Ioseliani // KINO-KOLO. - 2002. - №14. - S. 38.

20. Savchak, V. Uroky velykoho maistra / V. Savchak // Leninska molod (Lviv). - 1978. - 11 liutoho.

21. Vinhranovskyi, M. Khto i shcho dlia mene nezalezhnist Ukrainy / M. Vinhranovskyi // Den. - 2001. - 6 veresnia, № 159.

22. Nashi zemliaky - laureaty premii im. T. H. Shevchenka // Pivdenna pravda. - 1984. - 13 berez.

23. 23. Vynhranovskyi, N. Hod s uchytelem // Dovzhenko v vospomynanyiakh sovremennykov [Tekst] : Sbornyk. M. : Yskusstvo, 1981. — S. 231-233. 
24. Vinhranovskyi, M. Rik z Dovzhenkom / M. Vinhranovskyi // Vinhranovskyi M. Vybrani tvory / Mykola Vinhranovskyi; [peredm. L. M. Talalaia]. — K. : Dnipro, 2004. - S. 767775.

25. Vinhranovskyi, M. Rik z Dovzhenkom / M. Vinhranovskyi // Vinhranovskyi M. Vybrani tvory. U 3 t. T. 3. Povisti y opovid. / Mykola Vinhranovskyi ; [peredm. T. Salyhy]. — T. : Bohdan, 2004. - S. 342-350.

26. Vinhranovskyi, M. Holos talantu, muzhnosti i liubovi / Mykola Vinhranovskyi // Kurier Kryvbasu. - 1995. № 27 . - S. 18-20.
27. Vinhranovskyi, M. S. Chotyrnadtsiat stolyts Ukrainy: korotki narysy z yii istorii / M. S. Vinhranovskyi; Holov. red. L. N. Holovko, Per. z ukr. na rum. movu M. S. Liutyka, Khudozh. oform. Zh. Prysiazhnoi. - Kyiv : Holov. spets. red. 1-ry movamy nats. menshyn Ukrainy, 2002. $175 \mathrm{~s}$ : : il.

28. Bilan, A. Film pro druha yak spovid pered soboiu / A. Bilan // Ukr. kultura. - 2007. - № 3. - S. 13.

29. Lytvyn M. Tvoryv zhyttia, yak virsh / Mariia Lytvyn // Kultura i zhyttia. - 2007. - 14 berez. (№ 11). S. 2. 